DEPARTAMENTO DE TÉCNICA DE SAODE PUBLICA

(Diretor: Prof. Dr. G. H. de Paula Souza)

CADEIRA DE VENEREOLOGIA E LEPROLOGIA

Prof. Dr. J. M. Gomes

\title{
CULTURAS CROMOGENICAS ISOLADAS DE LEPROMAS MURINO E HUMANO
}

\author{
PROF. J. M. GOMES \\ e \\ LINDOLFO A. DE SOUZA
}

('Técnico)

I - LEPRA MURINA

O bacilo da lepra murina foi descoberto em 1903 por Stefansky, em Odessa.

Apresenta-se como um bastonete de 3 a 5 micra de comprimento. Sua morfologia é muito variável, sendo encontrado nos tecidos sob três aspectos principais: bacilo liso, curto ou longo, bacilo granuloso e bacilo fragmentado.

Corado pelo método de Ziehl-Neelsen, resiste à descoloração pelos ácidos ou pelo álcool. E' álcool-ácido-resistente.

Quando o organismo do rato oferece resistência ao parasitismo, o bacilo apresenta-se com uma ou duas granulações escuras, ou fica reduzido exclusivamente à granulação.

Morfològicamente é idêntico ao Mycobacterium de Hansen.

A virulência varia de cepa a cepa. Englobado o leproma em parafina e mantido na geladeira, perde a capacidade de infectar ratos ou camundongos, no fim de 24 meses, mas não perde a viabilidade.

\section{Tentativas de culturas}

H. Linhares ${ }^{1}$ condensando trabalhos relativos à lepra murina, enumera algumas dezenas de pesquisadores que isolaram colônias de vários matizes e bacilos de vários tipos morfológicos, tomando como ponto de partida lepromas de ratos.

Com exceção de Ota e Assami, nenhum afirma tei realizado o ciclo de Koch, condição que a maioria dos bacteriologistas impõe à aceitação da genuinidade de um germe isolado de uma lesão.

A nosso ver, o velho postulado do iniciador de isolamentos culturais já não pode ser mantido com o rigorismo dos primeiros dias da bacteriologia.

"Three to six anthrax bacilli taken directly from the blood of a dead animal regularly" - escreve Dubos" _ "cause the death of mice, whereas the MLD

1 LINHARES, H.: Contribuição ao estudo da lepra murina, Rev. brasil. de leprol., 12:217244 (set.), 1944.

2 DUBOS, R. J.: The Bacterial Cell, Cambridge, Harvard University Press, 1947. 
is increased several fold when the infective inoculum is taken from a 12-hour agar culture and becomes very much larger after several generations on agar".

Os germes de grande variabilidade morfológica não se podem enquadrár dentro de normas rígidas, e nestes casos estão aquêles que mais se aproxinam dos fungos, cujo polimorfismo tem levado ao absurdo de fazer surgir, temporàriamente, nova espécie para cada pesquisador que estuda o mesmo cogumelo.

Por fim, dá Linhares conta de suas próprias experiências, num total de 235 , em que procurou cultivar o M. de Stefansky, sem conseguí-lo.

Sua conclusão foi a seguinte: "Os resultados das culturas de bacilos da lepra murina são ainda muito dúbios, e nós somos ainda de opinião que o verda. deiro micro-organismo produtor da doença de Stefansky não foi cultivado",

O que já se escreveu com respeito à cultura dos Mycobacterium de Hansen e de Stefansky não cabe nas poucas páginas que reservamos ao histórico dêste trabalho. Quem desejar inteirar-se mais a fundo na matéria, leia o artigo, já citado, de Linhares, que condensou muito daquilo que se fez neste setor.

\section{Nossas pesquisas} Hansen.

Há mais de 10 anos andamos tentando a cultura dos M. de Stefansky e de

Por uma questão de método, faremos, por enquanto, referência ao primeiro. O segundo ficará para depois.

Lidando com inúmeros lepromas, sempre obtivemos o mesmo tipo de colô. nias e os mesmos aspectos bacilares.

Num estudo que se estende por tempo tão dilatado, é claro que não vamos dar publicidade aos protocolos guardados, com as muitas variantes por nós tomadas, algumas das quais foram embicar num ponto morto.

Outras vêzes era o estonteante polimorfismo do germe que nos desorientava, e desprezávamos aspectos morfológicos, que nos pareciam contaminação, quando mais tarde chegamos a compreender que se tratava de simples fase de uma bactéria de vasto ciclo evolutivo, cuja estabilização depende do tempo e de circunstâncias aparentemente despreziveis.

Assim, só descreveremos o método que conseguimos sistematizar em 1947, e de que vai descrita, abaixo, uma das experiências.

A 31-10-947 sacrificamos um rato com volumoso leproma não ulcerado, o qual foi retirado assèticamente, triturado e semeado em placas de agar-glicerinado a $5 \%$ e pôsto na estufa.

A 4 de novembro eram visíveis dois tipos de cultura. Naturalmente não se tratava de adaptação. Os germes cresceram à custa dos destroços de tecidos do rato, servindo o meio apenas de suporte.

As colônias eram: uma, alaranjada, quase ocre; a outra, còr de canário. Ambas pequenas e úmidas.

Lâminas da colônia ocre (Ziehl-Neelsen) : bacilos ácido-resistentes e elementos que designamos com o nome de "corpos fungiformes" ácido-sensíveis ou levemente ácido-resistentes.

A respeito do que chamamos "corpos fungiformes" teremos oportunidade de falar mais demoradamente. 
Lâminas da colônia côr de canário: granulações escuras, 2 a 2 ou 3 a 3; bacilos levemente ácido-resistentes.

Dia 5 de novembro: as colônias ocres são lisas. Retiranı-las da estufa.

Lâminas: bacilos lisos, intensamente ácido-resistentes, isolados ou em grupos compactos. Bacilos ácido-sensiveis. "Corpos fungiformes" de várias dimensões, ácido-resistentes, rodeados de membrana lisa, cheios de uma substância granulosa; outros achavam-se reduzidos à membrana, o centro claro. vazio, e em tôrno, bacilos fortemente ácido-resistentes.

Transplante para meio de Petragnani.

Nossa experiência anterior havia-nos mostrado que a colônia côr de canário representava uma fase mais atrasada da vida do bacilo, por isso, abandonamo-la.

Dia 8 de novembro: o germe desenvolveu-se, mas perdeu um pouco a ácidosistência, ficando, porém, granuloso, e as granulações, eram, na maior parte, escuras - o que parecia indjcar esfôrço de adaptação.

Dia 10 de novembro: de úmidas, que eram, as colônias vão ficando sêcas, e os bacilos começam a readquirir a ácido-resistência, restando, porém, muitos ácido-sensiveis.

Dia 22 de novembro: de ocre, a colônia vai-se tornando sulmáo e os bacilos reduzem-se a granulações fracamente ácido-resistentes.

Dia 1. ${ }^{\circ}$ de dezembro: a colônia é salmão, pastosa, levemente úmida. Retornam os bacilos ácido-resistentes, longos, granulosos.

Daí por diante, a cultura salmão estabilizou-se.

Vários pesquisadores fjcaram por aí.

Não nos contentamos com isso. As culturas discrepavam profundamente dos outros Mycobacteria isolados.

Retiramos de um dos tubos pequena porção e pusemos num tubo estéril, para . secar na estufa. No dia seguinte diluímos em água filtrada, cuja esterilidade havia sido verificada. O material assim diluído continuou na estufa por muis 24 horas e semeamos depois em Petragnani.

As colônias resultantes foram menos salmäo, isto é, havia zonas em que predominava côr alaranjada.

Os "corpos fungiformes" eram mais abundantes, variando o tamanho desde o de uma hemácia ao de um macrófago e mesmo mais. Proioplasma granuloso, membrana firme e nítida, outras vêzes só restava a membrana, e em tôrno uma coroa de bacilos curtos ou longos, fortemente ácido-resistentes.

As colônias continuavam pastosas, úmidas, a côr mais tsbatida, mas ainda não tinham o aspecto típico das culturas de bacilos ácido-resistentes.

Repetimos o secamento de uma alça da cultura, por 24 horas, diluímos em água filtrada e deixamos na estufa por 24 horas, semeando-a depois em Petragnani.

Nasceram, então, lado a lado, colônias salmão, lisas, levemente úmidas, e colônias alaranjadas, sêcas.

Isolamos esta última em Petragnani. Tomou aspecto sêco, granuloso, côr amarelo-claro, comparável, em tôda a linha, às culturas dos outros Mycobacteria.

Quando recentes, nestas colônias ainda se encontram alguns "corpos fungiformes", pequenos, e nos transplantes subsequentes desaparecem totalmente.

Por sua vez, os bacilos estabilizam-se. Tomam a forma de coco-bacilos, intensamente ácido-resistentes. Envelhecendo, enriquecem-se de granulações escuras. 


\section{Inoculações}

Inoculamos 9 ratos, na fossa ilíaca direita, em três séries, com os três tipos culturais obtidos: o salmão, liso, o salmão semeado de pontículos amarelos, mas ainda liso, e o amarelo-claro, granuloso.

Em vários bacilos dissociáveis, principalmente no grupo Gram-negativo, tem-se observado que a virulência é presente enquanto se ruantém a fase colonial lisa (S), e que ficam avirulentos, quando mudam para a fase grantlosa ou rugosa (R).

Uma semana depois sacrificamos um rato de cada série.

0 da $1 .^{a}$ série (salmão, lisa) apresentava a fossa ilíaca direita ligeiramente congestionada, e no esfregaço havia grupos de granılações ácido-resistentes.

$\mathrm{Na}$ série intermediária a congestão local era mais intensa e semeada de pequenos abscessos.

Lâminas: granulações ácido-resistentes e alguns bacilos ácido-resistentes vacuolados.

$\mathrm{Na}$ última série a congestão era maior ainda. Gânglios aumentados.

Lâminas: bacilos ácido-resistentes curtos ou longos, típicos, e massas de granulações ácido-resistentes.

Três meses depois, morre um rato da $1 .^{\text {a }}$ séi ie, por toxєmia e enconträm-se bacilos ácido-resistentes nas glândulas axilar direita, inguinal direita, fígado e granulaçóes escuras na axilar esquerda e baço.

Seis meses depois, morre o último rato da $1 .^{a}$ série, encontrando-se bacilos típicos nos esfregaços da glândula inguinal direita.

Sete meses depois da inoculação sacrificamos um rato du $2 .^{a}$ série. Magríssimo. Coberto de verrugas.

Lâminas: encontramos b.a.r. na glândula inguinal direita e nas verrugas.

$O$ último da mesma série foi também sacrificado no dia seguinte. Magrís. simo. Gânglios aumentados.

Lâminas: poucos b.a.r.

No dia seguinte foi sacrificado um rato da $3 .^{a}$ série.

Apresentava inúmeros abscessos na fossa ilíaca. Pús fluido. Lâminas: b.a.r. abundantes, em quase todos os órgãos.

No outro dia sacrificamos o último rato desta série. Abscessos. Só encontramos b.a.r. na glândula inguinal direita.

Não era nosso propósito demonstrar nesta pequena experiência que nossas culturas produziam lepra murina.

Procurávamos apenas saber qual o tipo cultural mais virulento, e, não hả dúvida que é o tipo liso $(\mathrm{S})$, vindo em seguida o tipo cultural de passagem.

Foi o tipo liso o único que determinou a morte dos ratos.

0 tipo granuloso ou rugoso $(\mathrm{R})$ deu oportunidade a que o organismo do rato preparasse a defesa, que se manifestou em mais intenso processo inflamatório e formação consecutiva de pequenos abscessos.

$$
\text { II - LEPRA HUMANA }
$$

Nossas tentativas de isolamento do M. de Hansen são contemporâneas das que empreendemos com o M. de Stefansky.

Os lepromas provieram do Asilo-Colônia de Santo Ângelo. 
Não descreveremos tudo o que foi feito no decurso de tanto tempo. Apenas nos deteremos no material recebido a 13-5-948.

Colhidos com tôda a assepsia, foram os lepromas englohados em parafina a 15 de maio e postos na geladeira.

Antes dessa operação, retirou-se um fragmento de tecido, triturou-se, suspendeu-se em solução fisiológica e semeou-se em placas de gelose glicerinada a $5 \%$, no dia $17-5-48$.

A 25-5-48 eram visíveis colônias ocres, moles, brilhantes.

Lâminas: coco-bacilos a.a.r. e granulações escuras.

No mesmo dia, transplante para Petragnani.

A 28-5-48, nesie meio, colônias úmidas, ocres, mais claras.

Lâminas: granulações a.a.r., grandes; granulações a.s.; alguns b.a.r.; "corpos fungiformes" a.a.r.

A 4-6-48, submetida uma alça da cultura a secamento, deixada, depois, 4.8 horas em água destilada e semeada em Petragnani, dá colônias amarelas, úmidas.

A 16-6-48, a colônia vai ficando salmão. E' pastosa e úmida.

Lâminas: $\operatorname{cocos~a.a.r.;~"corpos~fungiformes"~a.a.r.;~e,~em~tôrno,~granulações~}$ mais intensamente a.r. e alguns b.a.r.

A 21-6-48, novas semeaduras com o material já em coméco de coliquação.

A 30-6-48 eram visíveis dois tipos culturais: um ocre; outro quase salmão.

Fazendo agir o secamento de uma alça das culturas e rejplantando-a em Petragnani, conservado a $37^{\circ}$ ou à temperatura ambiente, obtínhamos sempre os mesmos tipos coloniais - ocre ou salmáo - com os caracteres anteriores ou levemente modificados, e os bacilos: a.s.; a.r.; corpúsculos a.s. ou a.r.; "corpos fungiformes", tudo misturado, e o meio de cultura, corado pelo verde malaquita, desmaiava.

Assim, atingimos os meados de setembro, sem chegar a nenhuma conclusão. As culturas típicas, que então possuíamos, uma das quais mandamos a Souza Araujo, foram obtidas sem que tivéssemos apanhado seu determinismo.

Nestas condições, deixamos os tubos no ambiente externo, e, com a experiência do M. de Stefansky, esperamos que envelhecessem.

Foi o replante dêstes tubos, estando já o mcio encarquilhado, que nos deu colônias sêcas, cromogênicas, granulosas, constituidas só de ccco-bacilos a.a.r.

Em 1949 retomamos o leproma guardado na geladeira.

Repetimos as provas iniciais e, em vez de lançar a cultura em Petragnani, passamos para caldo glicerinado a $5 \%$, a 28-5-49.

O meio ficou turvo a princípio. Clareou depois, com prơdução de menbrana amarela e farto depósito.

A 6.9-49 passamos para Petragnani.

A 9-11-49, já então sêco o meio, passamos de novo para o Petragnani.

Desenvolve-se lentamente, não descora o verde malaquita, e os germes são: b.a.r., delicados e coco-bacilos a.r.

Outro tubo de caldo glicosado, semeado a 2l-6-49, achava-se nas mesinas condições do anterior. Foi transplantado para Petragnani a 6-9.49.

Quase sêco, foi de novo passado a Petragnani.

Desenvolve-se lentamente, não descora o verde malaquita, e os germes são: b.a.r., ainda grosseiros; alguns agrupados. 
Mais velho e encarquilhado o meio, mais típicos os bacilos.

A exaustão do meio exerce o papel de agente da seleção riatural, permitindo apenas a sobrevivência das formas mais capazes.

\section{III - COMENTÁRIOS E DISCUSSĀO}

Contràriamente a outros micro-organismos patogênicos, o $\mathrm{M}$. da lepra só tem sido pròpriamente estudado em sua vida parasitária.

As inúmeras culturas obtidas por mais de uma centena de pesquisadores são de tal modo consideradas, que perdem logo as relações de contacto com o organismo de onde provieram e, como são avirulentas, não têm podido resistir à crítica.

Entretanto, esta questão de virulência, que é um atributo especial da célula microbiana, deve ser posta à margem no assunto que nos interessa, porque no próprio organismo humano há formas bacilares avirulentas ou destituídas de contágio, e ninguém se lembrou de considerá-las organismos banais.

$\mathrm{Na}$ lepra tuberculóide, por exemplo, quase sempre encontramos na parte pro. funda do derma b.a.r. e, não obstante sua presença, êste tipo clínico não oferece contagiosidade.

Em suas reações febris o número de bacilos chega mesmo a ser notável. Os germes apresentam quase todos os tipos bacteriológicos. Mas, se são incapazes de contágio, nem por isso deixam de provocar lesões progressivas no organismo, que parasitam.

Ch. Nicolle ${ }^{3}$, um sábio da nobre estirpe dos pensadores em bacteriologia, e cuja leitura é um fertilizador de experiência de laboratório, tratando do poder patogênico das bactérias, escreve: "L'aptitude pathogène est d'une telle labilité; elle naît, s'accroît, s'affaiblit, disparaît si aisément dans une même espèce microbienne, qu'il semble osé de la lier à un élément constitutif de la cellule."

E R. Duhos ": "Virulence is not a permanent, intrinsic property of a given species. It expresses only the ability of a given strain of the infective agent, in a certain growth phase, to produce a pathological state in a particular host. when introduced into that host under well defined conditions."

Os M. de Hansen e de Stefansky são parasitas adaptados, respectivamente, ao homem e ao rato e, apesar disso, o insucesso das inoculações, principalmente com o primeiro, tem sido de tal ordem, que já se invocou pretensa imunidade do adulto, para não chegar ao extremo de lançar anátema sôbre o Mycobacterium como agente causal da lepra.

A aceitação das formas granulares infra-microbianas veio dar novo alento às hipóteses de trabalho, quanto à etiologia.

Como a maior parte das pesquisas sôbre filtrabilidade dos M. de Hansen e de Stefansky foi feita sem contrôle, em 1936 um de nós ${ }^{5}$ publicou um trabalho sôbre inoculação de filtrados de uma cepa ativa de M. de Stefansky, controlando as experiências com a inoculação de bacilos lavados e centrifugados.

Não chegamos a leprolizar ratos, nem com filtrados, nem com bacilos lavados, mas observamos o seguinte: nos animais inoculados com os primeiros havia I

3 NICOLLE, Ch.: Destin des Maladies Infectieuses. Paris, Librairie Félix Alcan, 1933. 
multiplicação de bacilos até mais ou menos 60 dias, seu número depois declinava e do terceiro ao quarto mês tudo desaparecia.

A intimidade do fenômeno - infecção - continua ainda envolta em mistério, mas um fato se depreende de tudo isso: há no organismo inoculado ou in. fectado formas não virulentas ou destituidas de patogenicidade.

Ora, é sabido que os germes não patogênicos desenvolvsm-se, de um modo geral, com muita facilidade nos meios artificiais.

Não serão, porventura, os germes cultivados de lepromas formas degradadas?

Não temos, por enquanto, elementos para afirmar, de modo decisivo, que as culturas por nós obtidas sejam realmente os micro-organismos de Hansen e de Stefansky isolados.

A não ser a constância com que foram retirados, sempre com os mesmos caracteres, de lepromas de várias proveniências e de diferentes ratos inoculados, no decurso de mais de 10 anos, nada poderemos acrescentar a seu favor; mas, temos a impressão que, não só estas, como também muitas cutras culturas, isoladas por outros pesquisadores, sejam, de fato, as bactérias de Hansen e de Stefansky, num retôrno à vida saprofítica, pela adaptação aos meios de laboratório.

E' considerável o número de bacteriologistas que conseguiram culturas dêstes germes, mas parece que o acaso representou papel importante em seus achados, porque Lowe, Linhares etc., seguindo a mesma técnica ou enriquecendo-a com novos meios, falharam.

No decurso de nossa longa experiência, três fenômenos, pelo menos, se nos antolharam de capital importância: 1.") o envelhecimento do leproma, englobado, em parafina e conservado na geladeira; $2 .^{\circ}$ ) o secamento da cultura lisa, diluindo-a depois em água destilada, por 24 a 48 horas, a lim de que, lançada em meios fartamente nutritivos, dê abundantes formas de multiplicação; e $3 .^{\circ}$ ) o tempo, mediante o qual, pela exaustão do meio, sobrevivan apenas os bacilos mais capazes — os ácido-resistentes.

E. B. Mac Kinley ${ }^{6}$ informa que Rake, em 1888, conseguiu culturas lisas, "como gôtas de óleo", de três tipos: amarelo-canário, salmão e brancas, implantando em meios nutritivos, com sôro sanguíneo, "fragmentos de lepromas em decomposição".

E' o correspondente ao nosso envelhecimento do leproma, no qual se observa coliquação dos tecidos.

Para alcançar a colônia sêca, granulosa, comun aos Mycobacteria, só lhe faltaram os últimos têrmos da técnica, mediante os quais se chega às formas exclusivamente constituidas de b.a.r., cujo processo de rnultiplicação deve ser, principalmente, o da divisão binária, tal a lentidão de seu desenvolvimento.

Daí a conclusão de Rake, que não cultivara o bacilo.

Poucas vêzes temos logrado êxito com material imediatamente retirado do organismo vivo, e as poucas culturas alcançadas foram a preço de longa pernianência do tecido no meio cultural.

4 DUBOS, R. J.: Op. cit.

5 GOMES, J. M.: Pesquisas sôbre lepra murina, Rev. brasil. de leprol., 4:423-433 (dez.), 1936.

6 McKINLEY, E. B.: Bacteriology of leprosy; review, Internat. J. Leprosy, 7:1 (jan.março), 1939 
K. Schlosmann ${ }^{7}$ acha que são necessários 4, 5, 6 e mesmo 7 meses para se obterem culturas semelhantes às dos outros b.a.r.

WaIker L. Loving ${ }^{8}$ obteve cultura cromogênica, com b.a.r., usando a seguinte técnica: injetou triturado de leproma em coelhos, dos quais retirou material e inoculou em meio nutritivo, deixando-o na estufa 3 meses.

Os coelhos foram sacrificados no intervalo de 1 mês e 15 dias a 5 meses.

As colônias apareciam 2 meses e 15 dias depois, isto é, necessitavam de mais de 4 meses.

C. L. Trout ${ }^{9}$, que também teve êxito, empregou a seguinte técnica: $10^{\circ}$ ) ressecou os lepromas em condições asséticas; 2. ) lançou-os em sol. salina estéril; $3 .^{\circ}$ ) inoculou em meios próprios para o bacilo de Koch, a $37^{\circ}$, por 2 semanas a 4 meses.

As colônias eram côr de gema de ovo, os germes coco-bacilos a.r. ou b.a.r., alguns agrupados circularmente.

Como se vê, os processos variam e só há uma constante - o tempo. Deve ser o fator mais importante para obter a cultura.

Semeando, porém, o tecido coliquefeito, a adaptação torna-se mais fácil; e, pelo secamento de uma alça de cultura, antes de novo replante, aumenta-se o número dos "corpos fungiformes" a.r., meio pelo qual vamo: multiplicando com mais energia a formação de bacilos a.r.

Por fim, vem o tempo, como fator decisivo.

Algumas variantes neste processo foram dadas por um pesquisador patrício a quem muito deve a leprologia - Souza Araujo.

Souza Araujo é um daqueles que mais têm contribuido para o conhecimento do M. de Hansen.

Em "Mem. do Inst. O. Cruz", 1942, Fasc. I, dá conta de uma cultura cromogênica de um bacilo a.a.r. retirado do pus de uma lesão fechada da lepra humana.

O meio que empregou foi o de Löwenstein.

As primeiras colônias apareceram 13 dias depois da semeadura, mas só ficaram cromogênicas e granulosas e os bacilos típicos, 4 meses depois.

Mais tarde ("Mem. do Inst. O. Cruz", 1944, T. XL, fev.-junho), obteve culturas típicas do muco nasal, não só em Löwenstein, como em caldo glicerinado a $5 \%$, com incubação variando de 18 ou mais dias.

Suas pesquisas foram, porém, negativas, quando fez semeaduras da linfa cutânea dos lepromas.

Informa êle que neste material predominavam os cocóides ou coco-bacilus a.r.

E pergunta, então: "Por que não germinam?"

Por fim, acrescenta: "O determinismo do isolamento e cultura em meios artificiais do b. de Hansen ainda não está descoberto".

Mas, os melhores e mais constantes resultados, que alcauçou, foi por intermédio de ixodidas ou triatomas, que fez sugarem o sangue de doentes de lepra.

7 SCHLOSSMANN, K.: Cultivation of the Leprosy Bacillus, Resumo in Trop. Dis. Bull, 31 : 9-10 (jan.), 1934.

8 LOVING, W. L.: Cultivation in vitro of leprae with thiamin (vitamin B1) culture medium, Am. J. Trop. Med., 23:593.596 (nov.), 1943.

9 TROUT, C. L.: Cultivation of lepra bacillus, J. Trop. Med., 47:1-2 (fev.-março), 1944. 
As colônias apresentaram-șe típicas desde o $190^{\circ}$ ao $560^{\circ}$ dia de incubaçāo, e poucas foram as vêzes que teve de empregar a solurgão de ácido sulfúrico para a eliminação das formas ácido-sensíveis.

Estas pesquisas são muito interessantes sob vários aspectos:

1. ${ }^{\circ}$ - - Não há dúvida que a passagem através do apaılho digestivo dos insetos hematófagos usados como que depura o germe de sua complicada ciclogenia e facilita a adaptação aos meios artificiais.

Em apôio desta hipótese vem a própria observação do autor, quando diz acreditar que as grandes massas bacilíferas ("corpos fungiformes"?) encontradas nos carrapatos se tenham formado no organismo dêstes insetos.

Ora, nossos estudos mostram que, para alcançar mais ràpidamente a fase estável destas culturas, é mister provocar a formação abundante dêstes organismos de reprodução.

$\left.2 .^{\circ}\right)$ - Parece que se dá o mesmo fenômeno nas coleções purulentas, de onde o bacilo pode ser retirado em condições propícias à vida cultural.

3. ) - Na serosidade do leproma em franco estado parasitário, já a adaptação aos meios artificiais não se faz de golpe: o germe tem de passar pelos vários degraus de sua vasta ciclogenia, e só a exaustão do mè̀o, que é auxiliada pelo tempo (de 4 a 7 meses), nos proporciona as colônias cromogênicas com bacilos típicos.

Federico Solana y Gutiérrez ${ }^{10}$, referindo-se às relações dos bacilos ácido-resistentes com os fungos, assim se expressa: "Nosotros conocerros el bacilo de la lepra como aparece en el organismo, en su morfología parasitaria, en su adaptación animal, pero ignoramos cuál es su morfología saprofitaria.

"Por otra parte, la clasificación de los hongos se basa en la forma sexual de su reproducción, pero ocurre con este germen que apenas si la conocemos. En los tejidos se reproduce casi siempre por simple división o por brotes (yemas). La reproducción sexuada se verifica en la naturaleza?"

Ora, nossos "corpos fungiformes", abundantes nas culturas lisas, mais abundantes nas subculturas recentes, e mais ainda depois de submetidas ao secarnento e replantadas em Petragnani, não. serão, porventura, a reprodução sexuada da vida saprofítica.

Grifamos a expressão, levando em conta o que escreve Dubos (op. cit.): "The evidence presented to establish sexual reproduction in bacteria is not convincing. More fusion of cells does not necessarily mean sexual reproduction since this process implies a union of chromatin from two individuals. In fungi, for example, cells may be seen to fuse without any evidence of nuclear fusion and without formation of a reproductive body".

O que se dá com nossas culturas, relativamente aos "corpos fungiformes", faz lembrar o que se passa com certos fungos, nos quais as ascas só uparecem depois de processos violentos, como a cultura em meios pobres, o de Gorodkowa,

10 SOLANA y GUTIERREZ SOLANA, F.: Sobre el cultivo in vitro del bacilo de Hansen. Medicina de los Países Cálidos, 8:177, 233 e 271, ns, 4, 5 e 6 (abril, maio e junho), 1935. 
por exemplo, ou mesmo o giz. Faz apenas lembrar, porque nos fungos as ascas se formam no próprio meio pobre, ao passo que no nosso caso, êstes órgãos reprodutivos se vêem logo após o replante em meio rico.

Aliás, parece que a formação dêstes aparelhos reprodutivos é um fenômeno natural na fase ácido-sensível da bactéria, e sòmente na fase ácido-resistente é que há necessidade do emprêgo da violência. Dito de outra maneira: é unıa fa. culdade inerente à própria vida da célula bacteriana e que tem como finalidade a sobrevivência.

Exemplo: submetidas nossas culturas, já estabilizadas, à ação do promin, "in vitro" (J. M. Gomes ${ }^{11}$ ), e transportadas, de novo, para o meio de Petragnani, surgem logo êstes "corpos", que não existiam na cultura orighial, e acabam, por sua vez, desaparecendo, depois do segundó replante.

Estas formações "císticas" devem ser mais generalizadas na vida microbiana do que se imagina.

Abraham Gelperin ${ }^{12}$ observou nas culturas de Spirocheta reiter um tipo de multiplicação em que aparecem formas esféricas "em balão", na extremidade de germes, quando as condições do meio ficam desfavoráveis à propagação.

"Estes cistos - diz êle - contêm muitos corpos redondos, transparentes, que provàvelmente produzem espiroquetas, quando inocilados $\mathrm{cm}$ meio nutritivo fresco".

Os desenhos que acompanham o trabalho revelam grande semelhança com nossos "corpos fungiformes".

Dar-se-á também na vida parasitária a formação dêsses "corpos"?

Há já alguns anos estabeleceu Marchoux a diferença entre os aglomerados de bacilos, a que denominou - globias - àquilo que já Neisser observara, e que designou com o nome de - globi.

Êste últino não é seirão o fagocitismo bacilar.

A tal respeito é útil ler um trabalho de Souza Araujo ("Mem. do Irist. O. Cruz", de 1942).

Denney tratou também do assunto e faz referência à delicada membrana envolvente do aglomerado bacilar.

Malcolm Soule e Earl McKinley ${ }^{13}$ assim descrevem os bacilos da lepra: "The germs exist characteristically in clumps or bundles, like packets of cigars, composed of enormous numbers of rods. Most noticeable of all is the presence of both intracellular and extracellular global masses known as "globi", which are clumps of bacteria enclosed in a capsular material.";

Segundo Souza Araujo, deveria ser "globias" e não "globi".

O conhecimento dessas massas globosas no tecido humano vem de muito mais longe.

11 GOMES, J. M.: Ação do Promin, in vitro, sôbre Mycobacteria isolados de lepromas humanos, Arq. minei. leprol., 9:11-16 (jan.), 1949.

12 GELPERIN, A.: Morphology, cultural characteristics, and a method for mass cultivation by Reiter spirochete, Am. J. Syph., Gonor. \& Ven. Dis., 33:101-113 (março), 1949.

13 SOULE, M. H. e McKINLEY, E. B.: The Bacteriology and Immunology of Leprosy, in Tuberculosis and Leprosy. The Mycobacterial Diseases. Ed. Forest Ray Moulton, Symposium Series, Vol. I. The Amer. Assoc. for the Advancement of Science, 1938. 
Hansen, em sua comunicação sôbre o bacilo por êle descoberto, denuncia a presença de certas células de 0,006 a $0,0015 \mathrm{~mm}$, cheias de liacilos ou grânulos, mas, pela deficiência dos recursos laboratoriais de então, abstemo-nos de entrar por ela a dentro.

A micologia nos dá os mais belos exemplos de alterações morfológicas no esfôrço de adaptação.

Assim, os Paracoccidioides.

Nos meios artificiais desenvolvem-se sob forma filamentosa, segmentada e ra. mificada. Nas partes profundas já se encontram corpos oblongos ou ovais -- os clamidósporos; no organismo humano ou animal só se vêem formas redondas, de dupla membrana, cheias de granulações brilhantes.

Nas inoculações experimentais, penetrando no organismo sob o aspecto filamentoso, 6 dias depois só se encontram formas redondas.

Releva, porém, advertir que estas formas diferem fundamentalmente das nossas: estas só se apresentam quando, saindo de um ambiente esgotado, são os germes lançados num meio artificial rico, ao passo que o Paracoccidioides, qualquer que seja a fase da doença, mesmo ao seu declinar, pelo tratamento, só se apresentam como corpos redondos.

Volvendo agora ao nosso caso:

Não serão, porventura, nossos "corpos fungiformes" as "globias" de Marchoux?

Ao distender o esfregaço do tecido leprótico rompe-se a membrana, que é frágil. Fica apenas o aglomerado de bacilos, aderentes uns aos outros, por uma gleia ácido-resistente.

Estas massas bacilares não se apresentam em todos os períodos da lepra. Inexistentes ou raras em certo estado da doença; em outros elas dominam.

Poderíamos esquematizar as fases da infecção, baseados na bacterioscopia:

a) Penetração dos germes, sob qualquer dos seus aspectos — infra-microbiano, granulações a.s. ou a.r., b.a.r. ou b.a.s.

b) Esfôrço de adaptação, com a sobrevivência dos mais capazes.

Durante êsse período, que é longo e arrastadiço, a bacterioscopia, quando positiva, só denuncia bacilos esparsos.

Entram, então, os fatôres ambientes, que fazem da lepra uma doença social: puberdade, menopausa, estados infecciosos ou tóxicos, hiponutrição, miséria, guerras. E a resistência começa a declinar.

Temos, então, o seguinte:

c) A bacterioscopia começa a denunciar a presença de "globias", como nossas culturas, tendo sofrido o secamento na estufa (fator ambiental deprimente), são lançadas em meio nutritivo rico (Petragnani).

A presença das "globias" no homem observa-se na fase em que o organismo está pràticamente dominado, a fase anérgica, correspondente à zona culminante da parábola de Muir. 
$E$ as causas determinantes da entrada em cena do novo processo de multi. tiplicação, isto é, da formação de "globias", são as mesmas nue vão forcando o organismo a uma situação de tal ordem, que cai na absoluta inércia tecidual, de outro modo dito, em estado de anergia.

Mais tarde, na descida da curva, quando já se vem estabelecendo imunidade mais ou menos sólida, pela formação de anticorpos específicos, é possível que haja a faculdade potencial da produção de corpos globosos; mas o ambiente orgânico é que não apresenta facilidades, porque relativamente imunizado

E então a baciloscopia volta a ser esparsa.

$\mathrm{Na}$ lepra tuberculóide a resistência tecidual é maior. Fm alguns casos temos observado a presença de "corpos a.r.", sem, no entanto, spresentarem a mesma morfologia dos que encontramos nas culturas.

Vem a pêlo citar um caso, não de forma tuberculóide, nas incaracteristica, longamente tratado pelo promin, e que obtivera alta do Leprosário.

As lesōes haviarn desaparecido, persistindo a perturbação da sensibilidade.

Raspando com uma agulha a parte profunda do derma, encontramos bacilos a.r. longos, esparsos, vacuolados, como os que se vêem $\mathrm{em}$ certas fases de nossas culturas; agrupamentos globulares, rodeados de um halo claro ou de membrana tênue. Alguns dêstes "corpos" encerravam apenas granulaçães ácido-resistentes.

Devemos esclarecer que não distendemos o material. Puncionado o derma. fizemos espressão da pele. Surdiu uma gôta de sangue, sôbre a qual aplicamos a lâmina. Secamos, fixamos ligeiramente e coramos.

Nova espressão e tocamos outra gôta de sangue com un estilete mortado. Pusêmo-lo na estufa. Alguns dias depois retiramos o algodão da haste metálica e lançamos água destilada no tubo, que continuou na estufa.

Examinando o sedimento alguns dias depois, encontramos "corpos fungiformes", pàlidamente corados.

Submetida a doente, como fôra, a longo tratamento pelas sulfonas, desaparecidas as lesões, os germes restantes não haviam, entretanto, perdido a faculdade de gerar "corpos fungiformes", o que realmente se verificou, uma vez libertos da ação impediente dos anticorpos específicos e lançados num meio mesmo sem recursos, como a água destilada.

Em resumo:

As "globias" ou "corpos fungiformes" só aparecem no organismo na fase de estado, quando se esgota a resistência natural.

Nas formas tuberculóides aparecem também algumas vêzes, mas não chegam à maturidade devido à resistência oposta por um organismo alérgico.

Nas culturas, em que não há resistência conduzida, mas simplesmente esfôrço de adaptação, são abundantes na fase $\mathrm{S}$ da colônia. Depois desaparecem.

Queremos crer que êste fenômeno deva ser considerado como adaptação definitiva, com degradação da virulência: saprofitização.

O germe, porém, não perdeu a faculdade de produzir êsse outro tipo de multiplicação. Falta-lhe apenas o estímulo do meio nutritivo. Pois as granulações escuras, presentes em grande número de bacilos, ou livres, formas de resistência, 
que são, devem ser os elementos em que se realiza o procsso que dá como resultado a formação dos "corpos fungiformes".

Haja vista o que se observa nas culturas estabilizadas, depois da passagem em meio com promin.

E' possível que o estudo atento do que se passa na formação dêsses "corpos" lhe venha conferir um cunho de reprodução sexual.

Uma vez que tratamos dos M. de Hansen e de Stefansky, germes tão afins que é impossivel traçar-lhes qualquer diferença no aspecto morfológico, procuremos agora condensar-lhes a vida numa visão de unidade, dentro de uma concepção ciclogênica.

Comecemos pela vida parasitária.

R. Chaussinand ${ }^{14}$ admite no $M$. de Hansen 4 formas bacilares distintas:

1. ${ }^{a}$ ) - Bacilo normal, homogêneo, distinguindo-se em: longos, médios e curtos e bacilos finos.

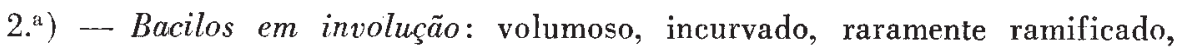
terminando às vêzes em clava.

E' uma forma de sofrimento do germe.

$3 .^{a}$ ) - Bacilo em divisão: composto de 2 ou 3 segmentos (reprodução por cissiparidade).

4. ${ }^{a}$ ) Bacilo em degeneração: no qual se vêem 4 formas distintas:

a) aparecimento de uma ou mais granulações mais carregadas;

b) perde a faculdade de se colorir e aparece uma cadeia de granulações;

c) as granulações dispersam-se;

d) transformam-se em poeira.

Não aceita a existência de uiltra-virus.

Em pesquisas com carotenóides, na lepra murina e humana, tentou um de nós (J. M. G. $)^{15}$ esquematizar a vida parasitária dos respectivos microrganismos, dando-lhe uma linha cíclica.

Para tanto, foram feitos exames de doentes em tratamento, retirando material sempre das mesmas lesóes, dentro de prazos determinados, até que os germes houvessem desaparecido.

14 Chaussinand, R.: Contribution à l'étude de la morphologie du bacille de Hansen, Ann. Inst. Pasteur, 73:660.665 (julho), 1947.

15 GOMES, J. M.: Tratamento da lepra à luz de novas idéias, S. Paulo, Emprêsa Gráfica da "Revista dos Tribunais", 1941. 
Estabelecemos, então, na vida do microrganismo duas fases distintas: evolutiva e involutiva, segundo o gráfico abaixo:

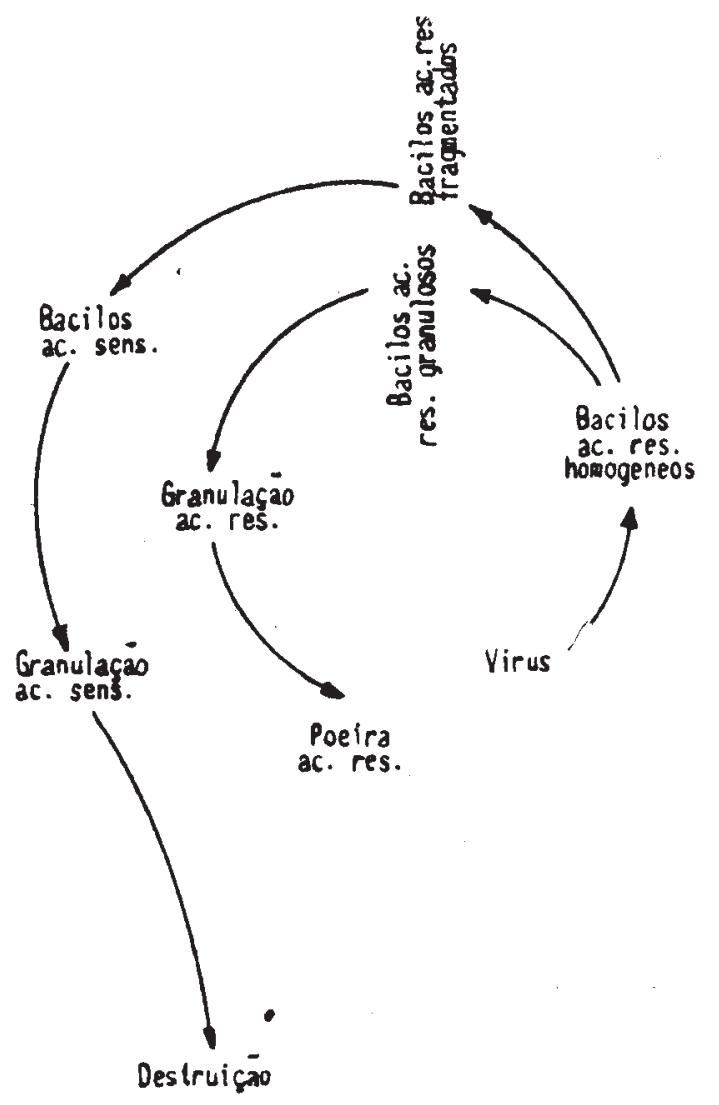

$\mathrm{Na} 1 .^{\mathrm{a}}$ fase admitíamos a seguinte seriação: virus (hoje preferimos a expressão - forma infra-microbiana), bacilo a.r. homogêneo, bacilo a.r. granuloso, granulação a.r., poeira a.r. e virus (aceitamos hoje que a poeira seja o têrmo final da dissociação bacilar).

$\mathrm{Na} 2 .^{\mathrm{a}}$ fase: virus (as mesmas considerações), bacilo a.r. fragmentado, bacilo a.s., granulação a.s..... destruição.

O tratamento da lepra pelas sulfonas veio revelar-nos outros tipos de involução do Mycobacterium: granulações a.r. ou a.s. grandes, maiores do que um estafilococo, fracamente coradas; formas bacilares a.s., grandes, encurvadas ou em clava, algumas vêzes vacuoladas, semelhantes, em tudo, ao que se vê nas culturas (ver desenho n. ${ }^{\circ}$ 6).

Estes aspectos são encontrados em zonas aparentemente sãs, assinaladas, an. tes, por infiltrações ou lesões acrômicas.

$\mathrm{Na}$ concepção da vida cíclica dos M. de Hansen e de Stefansky obedecemos não só à nossa própria experiência, como também às consideraçóes de Charles 
Nicolle (op. cit.), com respeito às granulações dos Mycobacteria: "Le cas du bacille lépreux est plus intéressant. On n'avait pas attaché, jusqu'à ces derniers temps, à ces formes granuleuses, l'importance et la signification qu'elles méritent. Les auteurs avaient bien signalé, depuis Hansen, que la plupart des bacilles, contenus dans les cellules lépreuses, sont constitués par un chapelet de granules. On voyait, dans ces bactéries granuleuses, des formes en voie de dégénérescence. Cette opinion n'est pas recevable. Comment concilier, en effet, l'évolution des lésions où ces formes sont si fréquentes avec l'hypothèse d'une destruction génerale, aisée, du microbe envahisseur?

"N'est-il pas plus logique d'admettre que de tels aspects figurent une multiplication par granules?"

$\mathrm{E}$ mais adiante:

"Tout se passe donc, en ce qui concerne le microbe de la lèpre, comme si sa seule forme active, aggressive, était le granule; la forme bacillaire ne représentant qu'un stade, destiné à se résoudre rapidement en une poussière de granules."

Para a consecıção do esquema acima, estudamos no próprio doente a ação de uma substância -- um carotenóide - que age eletivamente sôbre o Myco. bacterium de tal modo que provoca seu aparecimento nas lesñes de forma tuberculóide, nas quais o germe se encontra, geralmente, sob o aspecto granular ou infra-microbiano.

Discordamos, portanto, de Chaussinand, quando diz que as granulações escuras dos bacilos são formas degeneradas.

Pelo contrário: são formas de resistência.

Quando se trata a lepra pelas sulfonas, manifesta-se, de início, copioso aparecimento de granulações escuras, e do mesmo modo, "in vitïo", ao contacto das culturas do Mycobacterium com diluições convenientes destas substâncias.

E' pelas granulações escuras que o germe sobrevive e, enquanto houver no organismo estas formas germinais, há sempre o risco de uma recidiva.

E' a razão pela qual administramos carotenóides aos doentes, no fim do tratamento, para pôr à prova a inexistência destas granulações, porque, se elas forem presentes, a bacterioscopia será logo positiva, e o tratamento pelas sulfonas deverá continuar.

Em relação às culturas, não nos foi possivel seguir passo a passo sua evolução.

De um modo geral, parece que a adaptação aos meios artificiais se fêz no seguinte ritmo:

a) b.a.r., crescidos à custa dos destroços dos tecidos humano ou animal;

b) b.a.s., pequenos ou grandes;

c) formação de "corpos fungiformes" a.s.;

d) corpúsculos a.s.; alguns a.r. ou com núcleo a.r.;

e) b.a.s. finos e curtos; b.a.r., em pequeno número; os mesmos corpúsculos a.s. e a.r., em grande número. 
E. a cultura, úmida, pastosa, sem o aspecto das culturas de germes a r., cai em ponto morto.

Submetida a secamento:

f) grande número de "corpos fungiformes" a.r.;

g) corpúsculos e bacilos a.r., misturados a corpúsculos e bacilos a.s.

Novo ponto morto.

Insistindo em novos secamentos, apressa-se a estabilização da cultura; mas é o tempo - 4,5,6 ou 7 meses, que vai resolver a situação. Nesse interregno, o meio de cultura envelhece, fica às vêzes ressequido. Perecem todos os germes a.s. e, transplantado o material para o meio de Petragnani:

h) aparecem, por fim, colônias sêcas, granulosas, constituidas de cocobacilos a.r. E o Petragnani, com verde malaquita, que antes descorava, conserva sua côr.

Desde então a cultura se estabiliza e oferece o aspecto sêco e granuloso das colônias das outras bactérias a.r.

A conservação da colônia lisa, por vários meses, no caldo glicerinado a $5 \%$, dá o mesmo resultado do envelhecimento do meio sólido, porque as substâncias tóxicas, excretadas pelo germe, acabam por torná-lo impróprio à vegetação e só as formas resistentes (granulações escuras) sobrevivem.

\section{RESUMO}

Os AA. apresentam o resultado de mais de 10 anos de pesquisas, durante os quais, partindo de lepromas murinos e humanos, conseguiram, uma e muitas vêzes, isolar sempre o mesmo tipo de culturas cromogênicas, com bacilos a.a.r.

Os meios nutritivos usados foram: gelose glicerinada a 5\%, Petragnani e caldo glicerinado a $5 \%$.

As primeiras culturas obtidas discrepavam inteiramente do aspecto já conhecido e consagrado, das bactérias ácido-resistentes. Eram lisas, úmidas, de côr ocre ou salmão, e os germes, de extenso polimorfismo, em sua maior parte, a.s.

Tomando como norma nada desprezar de tudo o que se lhes apresentava, chegaram, por fim, a obter culturas cromogênicas típicas, constituidas, exclusivamente, de coco-bacilos a.r.

O microrganismo apresenta-se, pois, nos meios artificiais, sob dois aspectos culturais distintos: $10^{\circ}$ ) culturas lisas, úmidas, de côr ocre ou salmão; $2 .^{\circ}$ ) e em seguida, culturas amarelas, sêcas e granulosas.

No decurso de sua longa observação, três fatôres se lhes antolharam de capital importância: $1^{\circ}$ ) envelhecimento do leproma englobado, estéril, em parafina e conservado na geladeira; $2 .^{\circ}$ ) secamento de uma alça da culturu lisa, diluindo-a depois em água destilada, onde deve permanecer, na estufa, 24, ou 48 horas, semeando, então, em Petragnani.

Por meio dêstes processos de violência, comparáveis aos que se empregam para a obtenção de ascas, em certos fungos, formam-se, em grande abundância, 
órgãos a que denominaram "corpos fungiformes", interısamente a.r., cheios de corpúsculos ou mesmo bacilos, que vão sendo projetados em tôrno da membrana.

Êste processo de multiplicação vai assim aumentando o número de microrganismos a.r.; $3 .^{\circ}$ ) o tempo, mediante o qual, pela exaustão do meio nutritivo, os germes a.s. perecem, ficando apenas os de maior capacidade de adaptação os b.a.r.

Este processo de seleção natural necessita de alguns meses --- de 4 a 7 a partir da primeira semeadura.

Mostram, depois, que as "globias" de Marchoux -.- que dizem deverem ser diferençadas dos "globis" de Neisser - não são outra coisa senão os "corpos fungiformes", como se encontram nas culturas.

Nas colônias lisas, com germes na maior parte a.s., é natural êste recurso de multiplicação; mas, se se quiser forçar sua transformação em microrganismos a.r., ter-se-á de submeter a cultura à violência e inanição, a fím de que, lançada em meio nutritivo rico, se desenvolvam os "corpos fungiformes".

Sua multiplicação depende, pois, do sofrimento, seguido logo das facilidades do meio.

No organismo humano ou animal sua presença também se verifica na fase do estado da leprose, em que se observa tolerância absoluta ao parasitismo (comparável às facilidades do meio de Petragnani), isto é, uma situação anérgica.

$\mathrm{Na}$ primeira fase, em luta para a adaptação, os germes são esparsos (multiplicação por cissiparidade); na última fase, em luta com os anticorpos específicos, também são germes esparsos, e só retornam, ocasionalmente, às "globias", sob o império de outras condições infecciosas ou estado hiponutritivo.

Aceitando nos M. de Hansen e de Stefansky extenșa vida ciclogênica (Rev. Med. Brasil., 9:159-168, agôsto, 1940), traçam-lhes duas fases distintas, como parasitas: $1 .^{\mathrm{a}}$ ) fase evolutiva, na qual admitem: forma infra-microbiana, b.a.r homogêneo, b.a.r. granuloso, granulações a.r., poeiras a.r.; $2 .^{a}$ ) jase involutiva: in. fra-microbiana, b.a.r. homogêneo, b.a.r. fragmentado, b.a.s., granulações a.s.... destruição.

O tratamento pelas sulfonas veio revelar outros tipos de involução: granulações a.r. ou a.s. grandes, maiores do que um estafilococo, bacilos a.s. grandes, encurvados, vacuolados, em clava etc.

Quanto às granulações escuras, que aparecem no curso da infecção ou do tratamento, contràriamente ao que afirmam muitos autores, acham que são formas de resistência.

Em relação à morfologia dos germes nos meios de cultura, os autores descrevem as seguintes formas:
a) b.a.r., crescidos à custa dos destroços dos tecidos humano ou animal;
b) b.a.s., pequenos ou grandes;
c) formação de "corpos fungiformes" a.s.;
d) corpúsculos a.s.; alguns a.r. ou com núcleo a.r.;
e) b.a.s. finos e curtos; b.a.r. em pequeno número; os mesmos cor- púsculos a.s. e a.r., na maior parte, com núcleo a.r. 
E a cultura, úmida, pastosa, cai em ponto morto, sem o aspecto das culturas de bactérias ácido-resistentes. Submetida, então, a secamento, é observado o seguinte:

f) grande número de "corpos fungiformes" a.r.;

g) corpúsculos e bacilos a.r., misturados a corpúsculos e bacilos a.s.

Novio ponto morto é observado.

Insistindo-se em novos secamentos, apressa-se a estabilização da cultura, mas é o tempo - 4, 5, 6 ou 7 meses - que vai resolver a situação. Nesse interregno, - meio de cultura fica quase ressequido. Perecem todos os germes ácido-sensiveis e, transplantado o material para Petragnani, observa-se o seguinte:

h) aparecem, por fim, colônias sêcas e granulosas, constituidas, exclusivamente, por coco-bacilos ácido-resistentes, e o meio de Petragnani, com verde malaquita, que antes descorava, conserva sua côr.

Desde então, a cultura se estabiliza e oferece o aspecto típico, sêco e granuloso, das colônias das outras bactérias ácido-resistentes.

A conservação da colônia lisa, por vários meses, no caldo glicerinado a $5 \%$, dá os mesmos resultados do envelhecimento no meio sólido, porque as substâncias tóxicas elaboradas pelo microrganismo, acabam tornando-o impróprio à vegetação e só as formas resistentes (granulações escuras) sobrevivem.

\section{SUMMARY}

The AA. reports the results they obtained after more than 10 years of research, during which, starting from murine and human lepromas, he succeeded in isolating, many times, always the same type of chromogenic cultures of alcohol-acid fast bacilli.

Culture media used were: $5 \%$ glycerinated gelose, Petragnani and 5\% gli. cerinated broth.

The first cultures obtained differed entirely from the krown and accepted aspect of cultures of acid fast bacteria. They were smooth, inoist, of an ochre or salmon color; the organisms showed a great polymorphism and in the great majority were acid sensitive.

In the course of his studies the AA. made a point of not ignoring any of his findings; finally succeeding to obtain typical chromogenic cultures formed exclusively of acid fast cocco-bacilli.

The micro-organism appeared in the artificial culture media under two distinct aspects: 1st.) smooth, moist, ochre or salmon color cultures; 2nd.) following the first type, yellow, dry and granulated cultures appear.

In the course of his long period of observation, three factors seemed of the utmost importance to the AA.: lst.) aging of the leproma, which was kept sterile in the refrigerator, sealed in paraffin; 2nd.) drying of a wire loop taken from 
a smooth culture, diluting it later in distilled water and thus incubated for 24 or 48 hours and then planted in Petragnani's medium.

By means of these methods of "violence", comparable to those used for obtaining alea from certain fungi, a great number of organs are formed, which the AA. name "fungiform lodies", that are intensively acid fast, full of corpuscles or even hacilli. that are projected around the membrane.

This process of multiplication thus increases the number of acid fast bacilli.

3rd.) The length of time during which the orgarisms are kept in the same culture medium is important; once its nutritive properties are exhausted the acid sensitive organisms die, remaining only those of greater capacity of adaptation, viz., the acid fast hacilli.

This process of natural selection takes several months -- from 4 to 7 , counting from the first seeding.

Next the AA. demonstrate that the "grlobias" of Marchoux -- which must he differentiated from the "globis" of Neisser - are the same "fungiform bodies" found in the cultures.

In the smooth colonies, formed mostly of acid sensitive organisms, this method of multiplication is natural; however, if one wishes to force its transformation into acid fast organisms, one has to submit the culture to "violence" and starvation. in order that, seeding them in a more nutritive medium, "fungiform bodies" will be formed.

Is multiplication depends, therefore, of "suffering", followed by facilities offered by the more nutritive medium.

In the human ur animal body it is found in the phase of the leprotic state, in which absolute tolerance to parasilism is observed (a situation similar to that noted in Petragnani's medium), i.e., an anergic condition.

In the first phase. struggling to adapt themselves to the environmental conditions, the organisms are scattered (multiplication at this phase by fission); in the last phase. fighting the specific anti-bodies, the organisms are also found scattered and only occasionally they regress to the form of glolias, under the influence of other infections or hypo-nutritive conditions.

The AA. admit that the M. of Hansen and the M. of Stefansky have a long cyclogenic life ("Revista Brasileira de Medicina". Ausuct 1910) and distinguishes two phases of the M. as parasites: first evolutive, in which the AA. admit the following forms: infra-microbic, homogeneous acid fast bacillus, granulated acid fast hacillus, acid fast granulations and acid fast dusts; 2nd. -.. involutive phase: the following forms are observed in this phase: infra-microbic, homogeneous acid fast bacillus, fragmented acid fast bacillus, acid sensitive bacillus, acid sensitive granulations..... destruction.

Sulfona treatmerit brought out other types of involution: Large acid fast or sensitive granulations, even larger, than a Staphilococrus; large acid sensitive bacillus. curved, vacuolated, claviform, etc.

As to the dark granulations which appear in the course of the infection or trealment, contrary to many investigators, the $\mathrm{A} .4$. believe that they are forms of resistance.

Studying the morphology of the organisms in the culture media, the AA. describe the following forms: 
a - acid last hacilli, grown on débris of human or animal tissues;

b - large or small acid sensilive bacilli;

c - acid sensitive "fungiform bodies";

$\mathrm{d}$ - acid sensitive corpuscles; some are aid fast or with acid fast nucleus;

e - acid sensitive bacilli, thin and short; acid fast hacilli in small number; same acid sensitive corpuscles and acid fast in the great majority with acid fast nucleus.

And now the culture, moist, pasty, at a stand still. without the aspect of the cultures of acid fast bacteria. They are then submitted to dessication. The following is then observed:

$\mathrm{f}$ - a great number of acid fast "funwiform bodies";

$\mathrm{g}$ - acid fast corpuscles and hacilli, mixed with acid sensitive corpus. cles and bacilli; a new stand still is noticed.

If one insists on desscating the culture, its stahilization will be hastened; however, it is the lengih of time - 4, 5, 6, 7 months - . that is decisive. During that period of time culture medium is nearly completely dried out. All the acid sensitive organisms die. The material is now planted in Palragnani's. The following is observed:

h - finally, dry and granulated colonies appear, formed exclusively by a.r. coccobacilli; Petrachani"s nudium, with nalachite greet. which formerly became colorless, now keeps its color.

The culture now is stabilized and presents the rypical dspect (dry and granulated) of the colonies of other acid fast bacteria.

Conservation of smooth colonies for several months in $5 \%$ glycerinated froth gives the same results as the aging of the solid medium heralise the toxic substances elaborated by the micro-organism finally render it insuitable for vegetation and only the resistant forms (dark granulations) survive.

Agradecemos aos senhores Dr. P. Barros França. Bruno Mazza e Salvador Albani a concurso que nos deram para a execução dexte trabalho. 


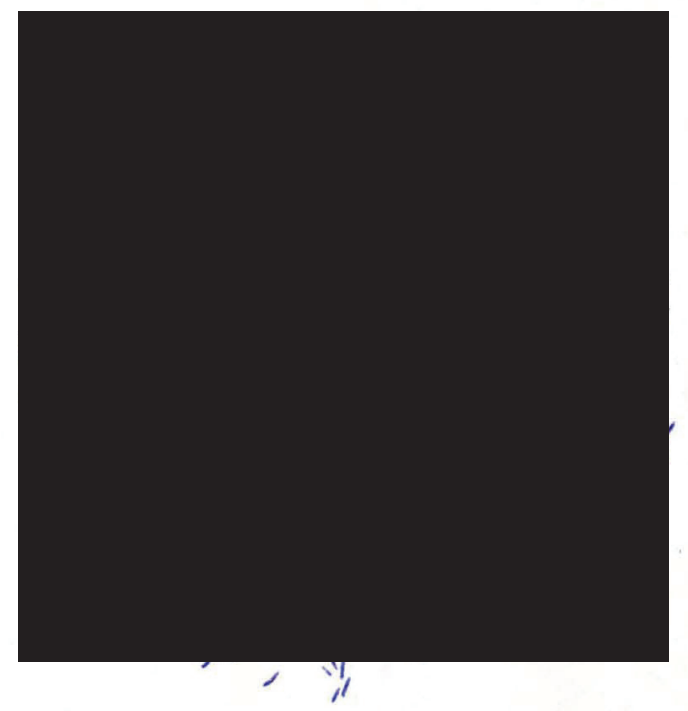

Fig. 1

Bacilos ácido-sensiveis no meio dos quais se vê um "corpo fungiforme" cheio ainda de corpúsculos ácido-resistentes (cultura lisa, lepra humana) Acid sensitive bacilli; among them a "fungiform body" is seem still full of acid fast corpuscles (smooth culture, human leprosy).

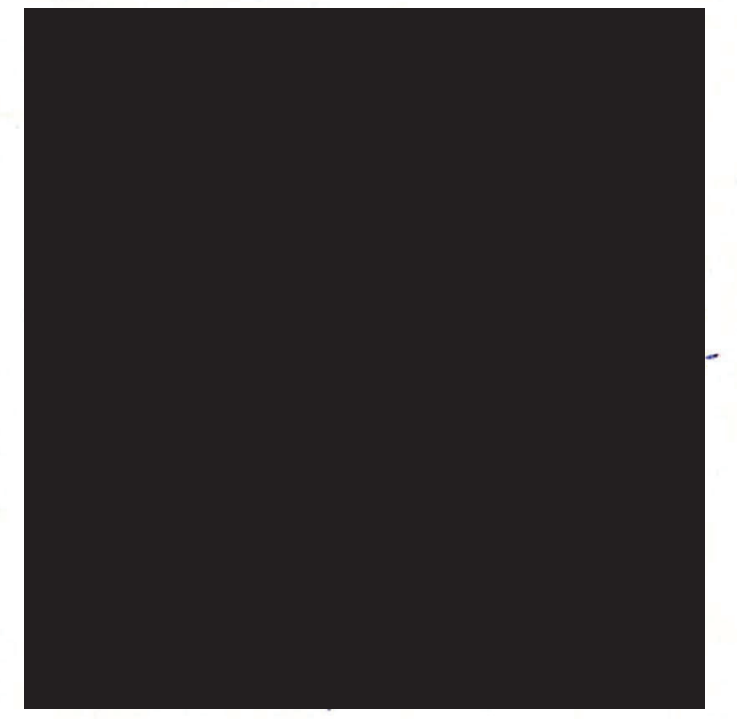

Fig. 2

"Corpo fungiforme" quase esvaziado (cultura lisa, lepra humana)

Nearly empty "fungiform body" full corpuscles (smooth culture, H. L.). 


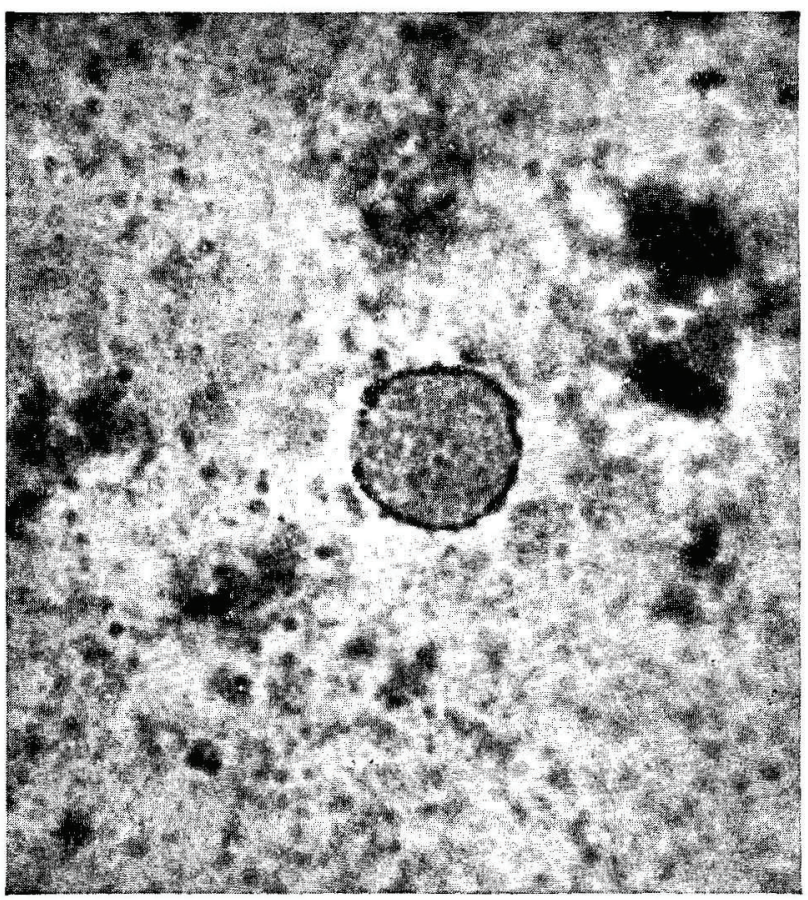

Fig. 3

"Corpo fungiforme" cheio de corpísculos (cultura lisa, lepra humana -.. fotografia)

"Fungiform body" full of corpuscles (smooth culture, human leprosy photograph).
Fig. 4

"Corpo fungiforme" ro deado de uma coroa de bacilos (cultura lisa, lepra murina - fotografia, grande aumento - 1.100 )

"Fungiform body" surrounded by bacilli (smooth culture, murine leprosy, photograph enlarged 1.100 times).

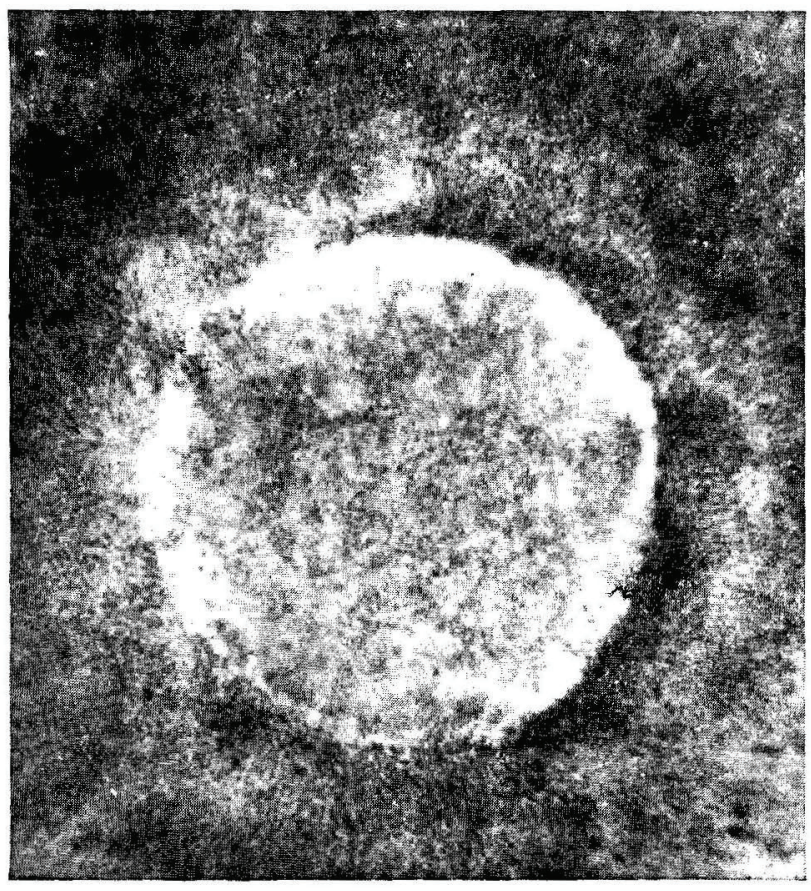




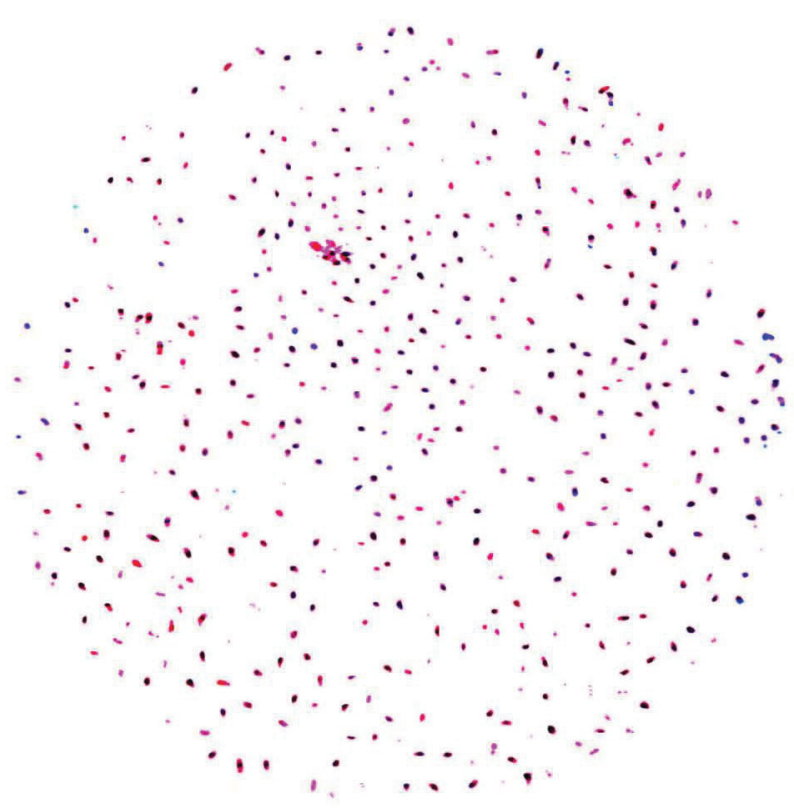

Fig. 5

Aspectos bacilares das culturas lisas (L. H.) Bacillary aspects of smooth cultures (human leprosy).

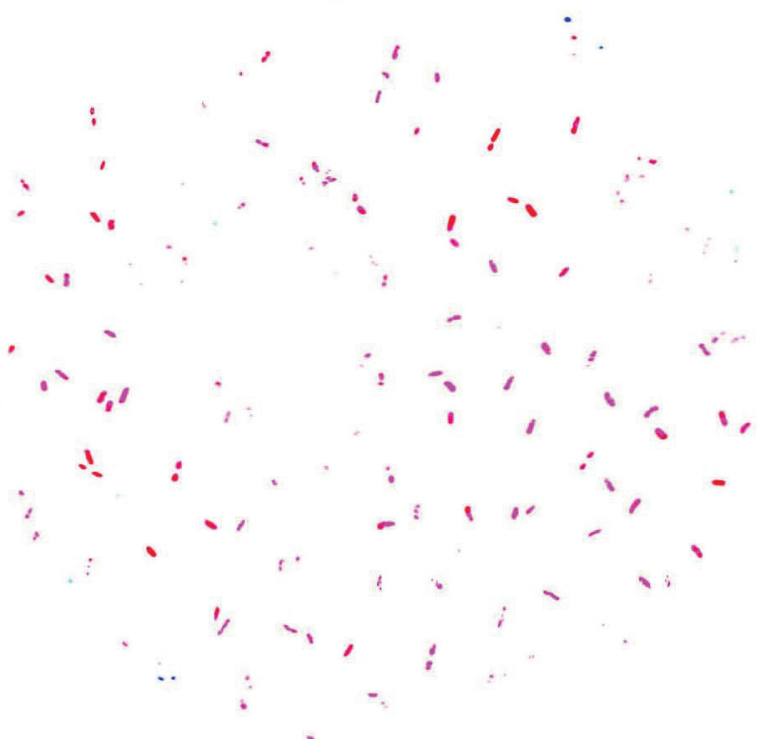

Fig. 6

Aspectos bacilares das culturas lisas (I. H.) Bacilla:y aspects of smooth culturis (human leprosy). 


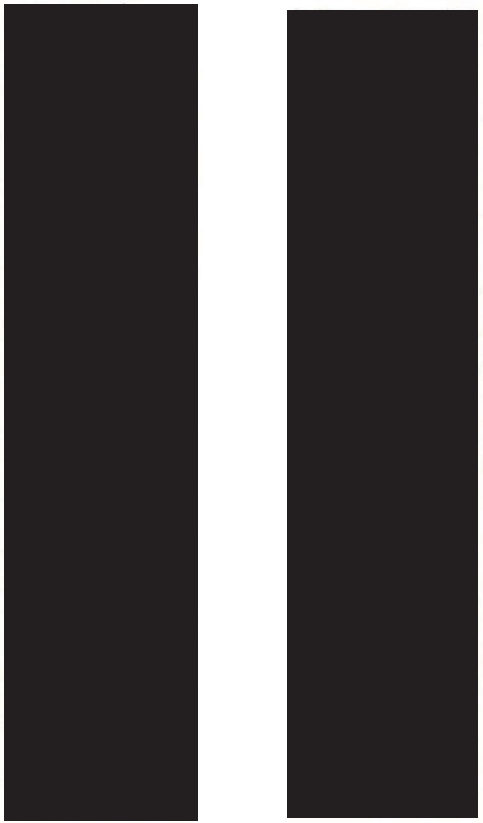

Fig. 7

Cultura granulosa estabilizada (L. H.).

Granulated culture, stabilized (human leprosy).

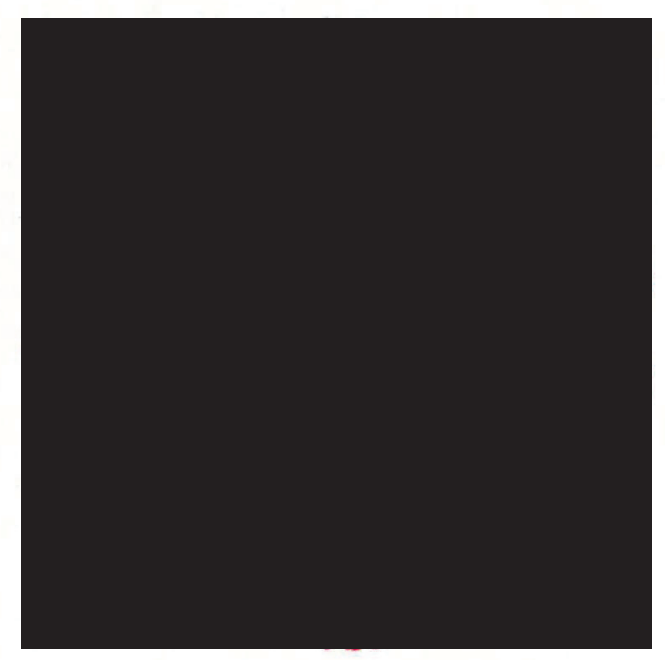

Fig. 8

Granulated culture, stabilized (murine leprosy).

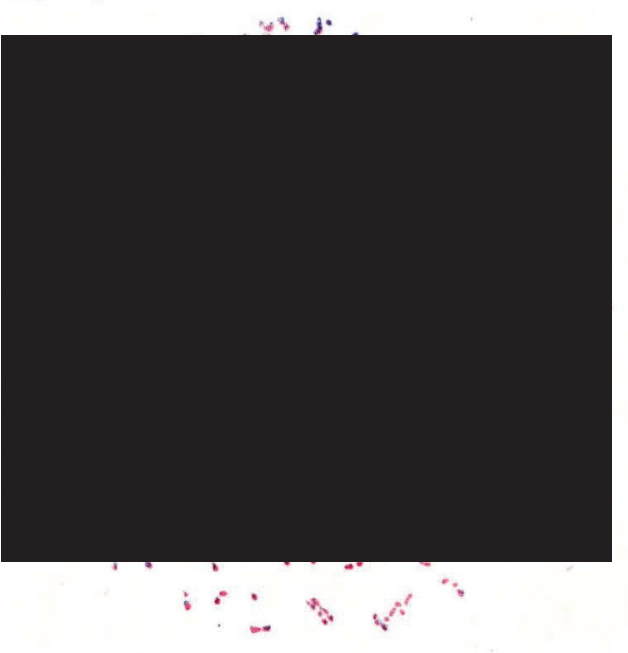

Fig. 9

Aspectos do microrganismo na cultura granulosa (L. H.)

Micro-organisms as seen in a granulated culture (human leprosy). 


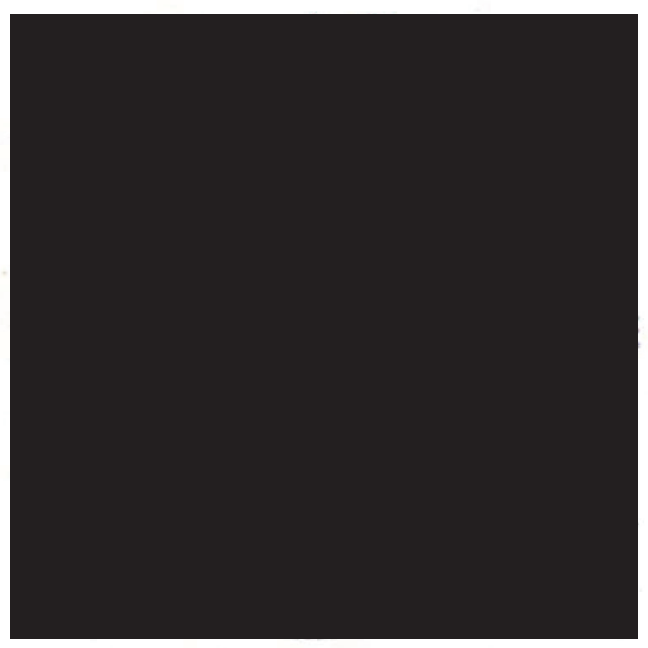

Fig. 10

Aspectos do microrganismo na cultura granulosa (L. M.)

Micro-organisms as seen in a granulated culture (murine leprosy).

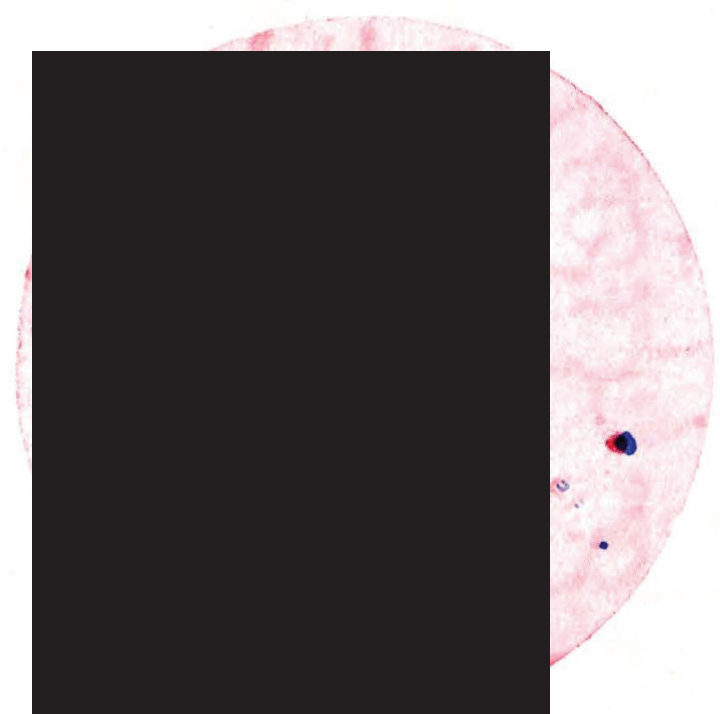

Fig. 11

Aspectos do microrganismo num caso de lepra tuberculóide tratado pelo promin. Formas idênticas se vêem nas culturas.

Micro organism as seen in a case of tuberculoid leprosy treated with promin. Similar forms are seen in the cultures. 


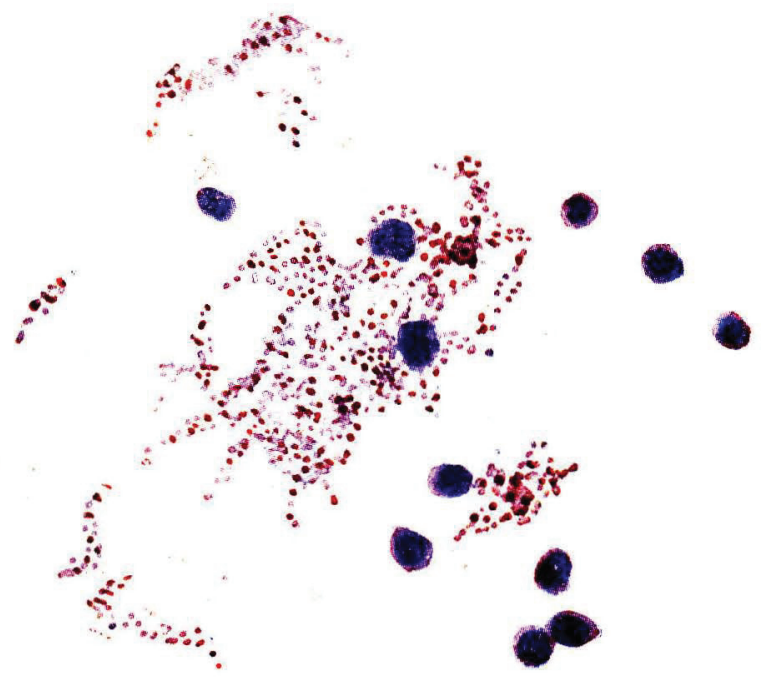

Fig. 12

Aspectos do microrganismo num caso tratado pelo promin. Zona onde existira lesão infiltrada. Formas idênticas se vêem nas culturas

Micro-organism as seen in a case treated with promin. Zone where there was an infiltrated lesion. Similar forms are seen in the cultures.

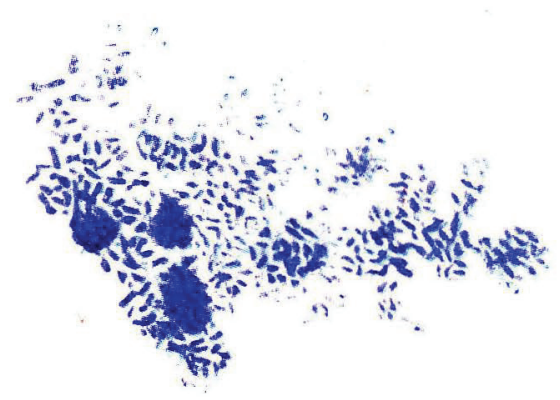

Fig. 13

Forma incaracterística tratada pelo promin. Esfregaço de serosidade de região onde existira lesão. Idênticos a certos aspectos das culturas lisas.

Uncharacteristic form treated with promin. Smear of serous material taken from a region of the body where there had been a lesion. These forms are identical with certain aspects of the smooth cultures. 